DOI: https://doi.org/10.24127/ajpm.v10i3.3779

\title{
PENGEMBANGAN MODUL BERBASIS PENINGKATAN KEMAMPUAN LITERASI STATISTIS SISWA
}

\author{
Iyam Maryati \\ Institut Pendidikan Indonesia Garut, Indonesia \\ *Corresponding author. \\ E-mail: iyammaryati@institutpendidikan.ac.id
}

Received 03 June 2021; Received in revised form 13 September 2021; Accepted 27 September 2021

\begin{abstract}
Abstrak
Literasi statistis adalah bagian dari literasi digital yang sangat penting dimiliki oleh siswa dalam era informasi ini. Strategi dalam meningkatkan kemampuan literasi statistis ini salah satunya dengan pengembangan pembelajaran menggunakan modul yang didesain untuk mengembangkan kemampuan literasi statistis. Penelitian ini bertujuan untuk mengembangkan modul statistika untuk mengembangkan kemampuan literasi statistis siswa Madrasah Tsanawiyah/ MTs dan Sekolah Menengah Pertama/SMP yang valid, praktis, dan efektif. Metode penelitian ini merupakan penelitian pengembangan (Research \& Development) dan menggunakan model pengembangan 4D (Define, Design, Develop, Dessiminate). Tehnik Analisis data yang digunakan adalah analisis deskriptif kualitatif. Subjek penelitian adalah siswa kelas VIII di salah satu MTs di Kabupaten Garut. Instrumen yang digunakan terdiri dari lembar validasi yang diisi oleh ahli bidang pendidikan matematika, lembar penilaian kepraktisan siswa, dan tes hasil belajar dengan soal literasi statistis. Kualitas modul yang dikembangkan ditinjau dari aspek kevalidan, aspek kepraktisan dan aspek keefektifan. Adapun hasil dari penelitian ini adalah modul termasuk kategori valid, dengan nilai kepraktisan termasuk kategori tinggi. Aspek efektifitas berdasarkan tes hasil belajar dengan soal literasi statistis mengalami peningkatan ditinjau dari hasil pretest dan posttest. Demikian juga dengan hasil pengembangan dalam penelitian ini adalah produk modul pembelajaran statistika yang valid, praktis dan efektif dan layak digunakan untuk siswa MTs/ SMP. Kontribusi dari penelitian ini adalah modul ini dapat digunakan dalam pembelajaran matematika dalam materi statistika.
\end{abstract}

Kata kunci: Kemampuan literasi statistis; modul.

\begin{abstract}
Statistical literacy is a part of digital literacy which is very important for students in this information age. One of the strategies to improve statistical literacy skills is the development of learning using modules designed to develop statistical literacy skills. This study aims to develop a statistical module to develop valid, practical, and effective statistical literacy skills for students at Madrasah Tsanawiyah/MTs (Junior Islamic Schools) and Sekolah Menengah Pertama/ SMP (Junior High Schools). This research method is a research development (Research \& Development). By using the 4D development model (Define, Design, Develop, Disseminate). The data analysis technique used is descriptive qualitative analysis The research subjects were students of class VIII at one of the MTs in Garut Regency. The instruments used consisted of validation sheets filled in by experts in the field of mathematics education, student practicality assessment sheets, and learning outcomes tests with statistical literacy questions. The quality of the developed modules is viewed from the aspects of validity, aspects of practicality and aspects of effectiveness. The result of this research is that the module is categorized as valid, with the practicality value is in the high category. The aspect of effectiveness based on the test of learning outcomes with statistical literacy questions has increased in terms of the results of the pretest and posttest. Likewise, the results of the development in this study are statistics learning module products that are valid, practical and effective and suitable for use for MTs/ SMP students. The contribution of this research is that this module can be used in mathematics learning in statistics material.
\end{abstract}

Keywords: Statistical literacy ability; module.

This is an open access article under the Creative Commons Attribution 4.0 International License 
DOI: https://doi.org/10.24127/ajpm.v10i3.3779

\section{PENDAHULUAN}

Kemampuan literasi statistis merupakan kemampuan seseorang dalam merespon informasi statistik yang meliputi kemampuan untuk menginterpretasi, mengevaluasi kritis, dan mengkomunikasikan informasi statistis. Literasi Statistik juga merupakan kemampuan untuk memahami dan mengevaluasi secara kritis hasil statistik yang meresapi kehidupan sehari-hari ditambah dengan kemampuan untuk menghargai kontribusi dari pemikiran statistik dalam keputusan publik dan pribadi, profesional dan pribadi (Hafiyusholeh et al., 2017).

Statistika merupakan materi yang dipelajari dalam mata pelajaran matematika mulai dari sekolah dasar sampai perguruan tinggi. Dalam statistika banyak sekali materi yang melatih untuk peningkatan kemampuan literasi statistis. Materi ukuran pemusatan data dan penyebaran data merupakan materi yang sangat menunjang dalam peningkatan kemampuan literasi statistis terutama pengumpulan data dan tampilan data (grafik, frekuensi, tabel, dan diagram lingkaran). Oleh karena itu, sangat penting bagi siswa untuk menguasainya agar memiliki kemampuan yang lebih baik dalam mata pelajaran matematika khususnya dalam materi statistika (Gravemeijer, K., Stephan, M., Julie, C., Lin, F., \& Ohtani, 2017).

Statistika adalah cabang ilmu dari matematika yang mempelajari tentang pengumpulan data, pengolahan data, penginterprestasian data, serta penarikan kesimpulan berdasarkan hasil analisis data (Sharma, 2017). Statistika juga merupakan salah satu materi (standar isi) yang dipelajari di kelas VIII SMP/MTs pada kurikulum 2013 di semester genap sehingga statistika merupakan materi yang sangat penting untuk dipelajari oleh siswa (As'ari, A. R., Tohir, M., Valentino, E., Imron, Z., \& Taufiq, 2017). Kemampuan dalam penguasaan statistika akan menjadi dasar dan prasyarat untuk penguasaan statistika di jenjang pendidikan tingkat lanjut (Furqoni \& Destania, 2020; Ruhyana, 2016).

Indikator kemampuan literasi statistis ini meliputi kemampuan memahami data, menginterprestasikan data, dan mengkomunikasikan data (Sabbag et al., 2018). Memahami data merupakan indikator yang sangat dasar, karena dalam kemampuan ini siswa dituntut untuk menyajikan kembali informasi-informasi atau data yang disajikan dalam soal atau permasalahan (Murod et al., 2019).

Menginterprestasikan data merupakan kemampuan untuk membuat koneksi atau kaitan antara data yang sudah dipahami dengan cara penyelesaiannya. Rumus penghitungan yang akan dipakai atau pun dalam penentuan cara atau metode yang digunakan (Masfingatin \& Suprapto, 2020). Mengkomunikasikan data meru-pakan kemampuan literasi statistis untuk memberikan kesimpulan atas keputusan yang diambil berdasarkan hasil dari pengolahan data atau inter-prestasi data (Priatna Martadiputra, 2012).

Kemampuan literasi statistis ini termuat dalam ruang lingkup kompetensi yang dibebankan dalam materi pembelajaran matematika di MTs/ SMP yang diatur dalam standar isi kurikulum 2013. Dalam lingkup materi statistika siswa diharapkan memiliki kompetensi mema-hami konsep, memberikan interprestasi terhadap berbagai macam metode penyajian data, menggunakan simbol, mengidentifikasi informasi, dan menerapkan strategi lain dalam penyelesaian permasalahan (Kemdikbud, 2017). 
Beberapa penelitian yang relevan menunjukkan siswa masih mengalami kesulitan dan kesalahan dalam mengerjakan soal kemampuan literasi statistis. Kesalahan dalam mengerjakan soal sering terjadi akibat dari miskonsepsi terhadap materi statisstika (Lestari et al., 2018). Kesalahan atau kesulitan yang sering dilakukan oleh siswa diantaranya adalah: 1) Kesulitan dalam memahami informasi atau data yang muncul dalam permasalahan. 2) Tidak dapat menentukan apa yang harus diasumsikan dari informasi atau data yang disajikan. 3) Kesulitan dalam melakukan interprestasi terhadap data sehingga tidak mampu melakukan penghitungan atau pengolahan data. 4) Cenderung menebak jawabannya tanpa proses berpikir, 4) Siswa tidak sabar dan tidak suka membaca soal matematika, dan 5) Siswa tidak suka membaca soal yang panjang (Hariyanti, 2020; Irawati, 2017; Maryati \& Priatna, 2018; Nahdi et al., 2021; Ruhyana, 2016; Tiro, 2018). Berdasarkan beberapa hasil penelitian terdahulu tersebut dalam penyelesaian soal literasi statistis masih dianggap sulit oleh sebagian besar siswa.

Peningkatan kemampuan literasi statistis siswa diperlukan peran penting dari guru untuk memberikan fasilitas kepada siswa untuk mengembangkan kemampuan literasi statistis tersebut. Pada pembelajaran, guru sangat berperan untuk menciptakan suasana pembelajaran dengan metode yang tepat, salah satunya adalah dengan membuat modul. Dalam materi statistika ini pengembangan bahan ajar sangat bermanfaat sekali (Jamil A, Cahyono H, 2021; Pujiastuti, H. \& Haryadi, 2021).

Modul pembelajaran dapat memudahkan mahasiswa berlatih soalsoal kemampuan literasi statistis secara mandiri. Pembelajaran matematika dalam materi statistika dengan menggunakan modul terbukti efektif (Nu'man, 2019) dan dapat meningkatkan kemampuan literasi statistis siswa (Muzaki, L., Slamin., 2014; Rembulan et al., 2018). Dengan demikian, berdasarkan penelitian terdahulu tersebut, dapat dilihat bahwa modul pembelajaran bisa menjadi solusi yang baik untuk meningkatkan kemampuan siswa khususnya dalam kemampuan literasi statistis. Oleh karena itu, pengembangan modul pembelajaran perlu untuk dilakukan.

Kontribusi dari modul yang dikembangkan dalam penelitian ini adalah modul ini merupakan modul dalam materi statistika siswa yang berorientasi untuk mengembangkan kemampuan literasi statistis, sehingga soal-soal pada modul dirancang untuk meningkatkan kemampuan literasi statistis. Soal-soal pada modul ini terdiri dari contoh soal, latihan soal dengan petunjuk jawaban dan latihan soal dengan kunci jawaban.

Dengan demikian, tujuan penelitian pengembangan ini yaitu: (1) menghasilkan modul statistika untuk siswa MTs/ SMP yang valid, praktis dan efektif, dan (2) mendeskripsikan kevalidan, kepraktisan dan keefektifan modul pembelajaran statistika untuk meningkatkan hasil belajar.

\section{METODE PENELITIAN}

Metode dalam penelitian ini adalah penelitian pengembangan (Research \& Development). Modul yang dikembangkan dalam penelitian ini adalah modul statistika untuk meningkatkan kemampuan literasi statistis siswa kelas VIII MTs/ SMP. Subjek penelitian dilakukan pada siswa kelas VIII-D Mts Negeri 3 Garut. Model pengembangan menggunakan 
model Four-D (4-D) yang terdiri dari empat tahap pengembangan, yaitu Define (pendefinisian), Design (desain), Develop (pengembangan), Desseminate (penyebaran) (Thiagarajan, S., Semmel, D. S. \& Semmel, 1976).

Uji kualitas dilakukan untuk memperoleh prototipe hasil dari penelitian pengembangan yang berkualitas. Aspek-aspek yang berkaitan dengan kualitas prototipe meliputi aspek kevalidan, kepraktisan, dan keefektifan. Aspek Kevalidan merupakan penilaian dari satu orang validator yang merupakan dosen Pendidikan matematika di salah satu perguruan tinggi swasta di kabupaten Garut, dengan latar belakang pendidikan doktoral bidang pendidikan matematika, dan dua orang validator guru matematika di salah satu Madrasah Tsanawiyah di kabupaten Garut dengan latar belakang Pendidikan Magister Pendidikan matematika. Aspek kevalidan meliputi aspek materi; soal dan Latihan; Bahasa dan tampilan; ilustrasi tabel; dan manfaat.

Aspek kepraktisan merupakan penilaian dari siswa kelas VIII-D setelah mendapatkan pembelajaran menggunakan modul. Penilaian aspek kepraktisan meliputi: 1. Kepraktisan Modul untuk Materi per Bab yang menyangkut materi: a) ukuran pemusatan data yang meliputi mean, median, dan modus; b) Ukuran Penyebaran data yang meliputi jangkauan, kuartil, jangkauan antar kuartil, dan simpangan kuartil. 2. Kepraktisan dari aspek penilaian: a) Jenis tulisan, ukuran huruf dan bahasa; b) Isi modul (gambar, tabel, uraian materi dan rangkuman); c) Contoh soal dan latihan untuk kemandirian kemampuan Literasi Statistis; d) Modul secara umum untuk kemandirian dan kemamapuan literasi statistis.
Aspek keefektifan dilihat dari hasil belajar siswa menyelesaikan soal literasi statistis setelah memperoleh pemebelajaran menggunakan modul.

Penelitian ini lebih fokus pada prosedur pengembangan atau desain produk berupa modul statistika untuk kemampuan literasi statistis. Langkahlangkah pada prosedur penelitian ini sebagai berikut: a) Tahap pendefinisian, menentukan masalah dasar dan menetukan materi dan tujuan modul statistika. b) Tahap perancangan, pembuatan dan penulisan draft modul. c) Tahap pengembangan, validasi ahli oleh doktor bidang pembelajaran matematika dan peneliti bidang statistika, analisis data validasi dan revisi awal, uji coba, analisis data hasil uji coba dan revisi akhir. d) Tahap penyebaran, menerapkan modul kepada siswa untuk mengetahui tanggapan siswa terhadap modul yang digunakan.

Instrumen penelitian terdiri dari lembar validasi modul, lembar penilaian modul dan soal statistika untuk mengukur kemampuan literasi statistis siswa. Lembar validasi modul diisi oleh validator untuk mendapatkan data hasil validasi. Lembar penilaian modul diisi oleh siswa untuk mendapatkan data kepraktisan hasil uji coba. Siswa mengerjakan soal statistika setelah pembelajaran menggunakan modul untuk mengetahui keefektifan modul dalam meningkatkan kemampuan literasi statistis.

Teknik analisis data untuk kevalidan modul dilihat dari nilai ratarata total aspek penilaian berdasarkan langkah-langkah berikut:

Menentukan nilai rerata total dari rerata nilai untuk semua aspek (Va) dengan rumus (1):

$$
V a=\frac{\sum_{i=1}^{n} A_{i}}{n}
$$


dengan $\mathrm{A}_{\mathrm{i}}$ adalah nilai untuk aspek ke-i dan $n$ adalah banyaknya aspek.

1. Nilai Va ini digunakan pada interval penentuan tingkat kevalidan yang dapat dilihat pada Tabel 1.

Tabel 1. Kategori tingkat kevalidan

\begin{tabular}{ccc}
\hline No & Rentang & Kategori \\
\hline 1 & $1 \leq \mathrm{Va}<2$ & Tidak Valid \\
2 & $2 \leq \mathrm{Va}<3$ & Kurang Valid \\
3 & $3 \leq \mathrm{Va}<4$ & Valid \\
4 & $\mathrm{Va}=4$ & Sangat Valid \\
\hline
\end{tabular}

3. Data penilaian siswa untuk melihat kepraktisan dianalisis sama seperti dengan aspek kevalidan. Aspek kepraktisan (Pr) menggunakan kategori penilaian siswa seperti pada Tabel 2.

Tabel 2. Kategori tingkat kepraktisan

\begin{tabular}{ccc}
\hline No & Rentang & Kategori \\
\hline 1 & $1 \leq \operatorname{Pr}<2$ & Sangat rendah \\
2 & $2 \leq \operatorname{Pr}<3$ & Rendah \\
3 & $3 \leq \operatorname{Pr}<4$ & Tinggi \\
4 & $\operatorname{Pr}=4$ & Sangat tinggi \\
\hline
\end{tabular}

(Azwar, 2012).

4. Aspek efektifitas dianalisis dengan melihat peningkatan kemampuan literasi statistis, dengan memperhatikan peningkatan nilai yang dialami siswa antara nilai pretest dengan posttest. Apabila terdapat siswa yang memperoleh peningkatan nilai lebih dari $75 \%$ yang memiliki nilai di atas KKM yaitu 65 maka modul dapat dikatakan efektif.

\section{HASIL DAN PEMBAHASAN}

1. Deskripsi Tahap Pendefinisian

a. Analisis Pendahuluan

Data analisis awal akhir ini didapat dari hasil survei pendahuluan dan wawancara dengan guru matematika kelas VIII, survei pendahuluan kepada siswa yang sudah memperoleh materi statistika (kelas IX).

Berdasarkan hasil wawancara dengan guru matematika diperoleh informasi bahwa: 1) guru dalam mengajar menggunakan buku yang sudah ada, belum sempat membuat modul atau bahan ajar sendiri, 2) guru lebih sering mengajarkan tentang pemahaman konsep dan rumus, jarang mengajarkan tentang kemampuan literasi statistis, 3) pernah memberikan soal kemampuan literasi statistis, namun kemampuan menjawab soal literasi statistis masih kurang dimiliki siswa.

Berdasarkan hasil survei pendahuluan kepada siswa diperoleh informasi bahwa 10 dari 15 siswa merasa kesulitan menyelesaikan soal literasi statistis. Selanjutnya siswa belum terbiasa dan termotivasi untuk mengerjakan soal-soal kemampuan literasi statistis, mereka cenderung menyerah lebih dahulu sebelum mencoba menjawab dan lebih memilih mengerjakan soal-soal rutin tentang pemahaman konsep saja. Sebagian besar siswa tidak memiliki buku referensi dan hanya belajar menunggu materi dari guru saja. Di samping itu, menurut siswa modul sebagai penunjang atau referensi yang baik sehingga memudahkan mereka untuk memahami materi statistika.

Selain itu, informasi lain yang diperoleh yaitu tentang karakteristik modul yang diinginkan siswa diantaranya adalah modul tersebut harus banyak menyediakan contoh soal lierasi statistis beserta penyelesaiannya, disajikan juga kunci jawaban untuk memudahkan siswa mengoreksi jawabannya sebelum bertanya kepada guru, dan memiliki rangkuman yang memudahkan siswa untuk mengingat rumus-rumus. Kemudian, modul memuat materi, latihan, soal dan pemahaman konsep 
yang rinci dan jelas serta literasi statistis disertai petunjuk penyelesaian yang jelas sehingga mudah dipahami. Karakteristik selanjutnya ialah modul yang menjelaskan konsep pada setiap materi secara detail serta dilengkapi soal literasi statistis yang terdiri dari soal mudah sampai soal yang susah.

Berdasarkan hasil wawancara dan survei pendahuluan tersebut didapatkan kesimpulan bahwa kemampuan literasi statistis penting untuk dikembangkan dalam pembelajaran statistika. Salah satu cara yang efektif menurut siswa sebagai peserta didik untuk meningkatkan kemampuan literasi statistis siswa pada maeri statistika adalah menggunakan modul dengan karakterisik modul memuat materi, latihan, soal dan pemahaman konsep yang rinci dan jelas serta literasi statistis dilengkapi dengan petunjuk penyelesaian yang jelas sehingga mudah dipahami oleh siswa.

\section{b. Analisis Materi}

Berdasarkan hasil wawancara analisis pendahuluan didapatkan materi yang perlu dikembangkan pada modul statistika ini adalah: 1. Ukuran Pemusatan data yang meliputi mean, median, dan modus; 2. Ukuran Penyebaran data yang meliputi jangkauan, kuartil, jangkauan antar kuartil, dan simpangan kuartil.

\section{c. Spesifikasi Tujuan Pembelajaran}

Spesifikasi tujuan pembelajaran merupakan dasar penyusunan rancangan modul statistika. Setelah mengikuti pembelajaran menggunakan modul statistika siswa dapat: 1) Siswa mampu menganalisisi data dari distribusi data yang disajikan. 2) Siswa mampu menentukan rata-rata (mean) dari suatu kumpulan data. 3) Siswa mampu menentukan median dan modus dar suatu kumpulan data. 4) Siswa menentukan sedaran data yang meliputi jangkauan, uartil, jangkauan interkuartil, dan semi kuartil. 5) Siswa mampu menyelesaikan permasalahan yang berkaitan dengan distribusi data, rata-rata, median, modus, dan sebaran data dari suatu kumpulan data. 6) Siswa mampu membuat kesimpulan, mengambil keputusan, dan membuat prediksi dari suatu kumpulan data berdasarkan sebaran data, mean, median, modus dan sebaran data.

\section{Deskripsi Tahap Perancangan}

Tahap Perancangan, pembuatan dan penulisan draft modul. Modul ini berisi materi statistika dilengkapi dengan soal-soal latihan, baik soal pemahaman konsep maupun soal literasi statistis. Rancangan isi modul ini terdiri atas cover, kata pengantar, daftar isi, judul materi, tujuan pembelajaran, uraian materi, contoh soal materi statistika, contoh soal literasi statistis, rangkuman, latihan soal pemahaman konsep, panduan menjawab dan uraian cara penyelesaian, latihan soal literasi statistis, panduan menjawab dan kunci jawaban, tes ujian akhir bab (soal pemahaman konsep dan literasi statistis) dan kunci jawaban. Adapun tampilan pada modul, dapat dilihat pada Gambar 1, Gambar 2, dan Gambar 3.

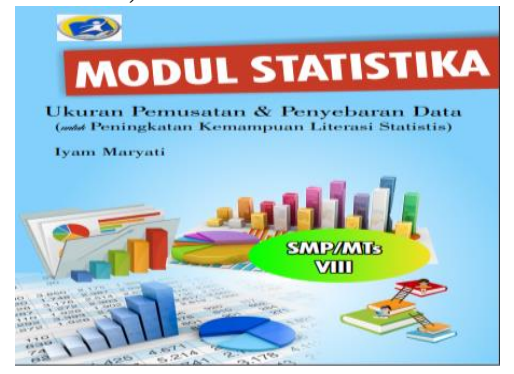

Gambar 1. Cover Modul 
DOI: $\underline{\text { https://doi.org/10.24127/ajpm.v10i3.3779 }}$
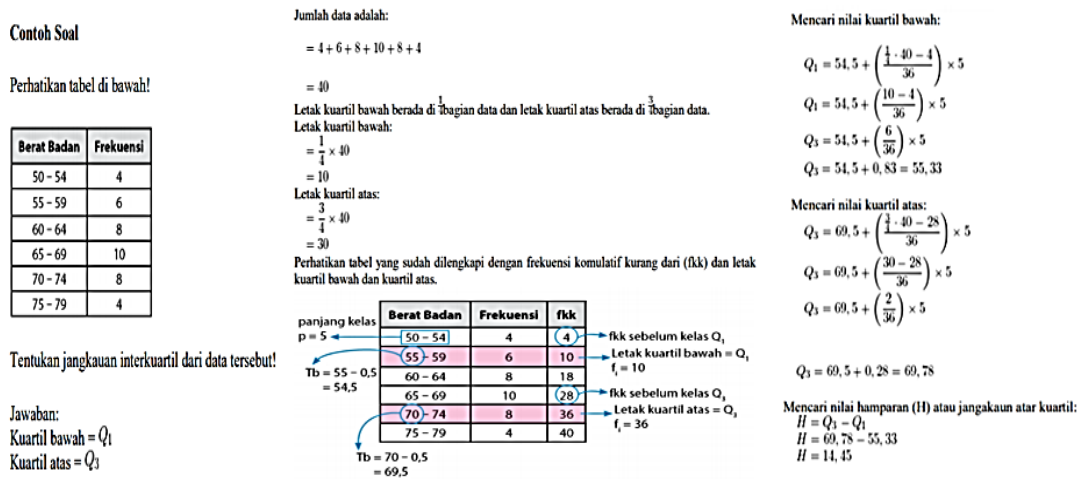

Gambar 2. Contoh soal dan Penyelesaian

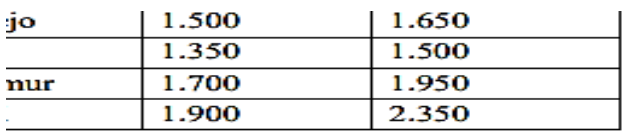

batang dan diagram garis dari data tersebut? tentang banyaknya penduduk laki-laki da

Gambar 3. Soal Latihan Kemampuan Literasi Statistis

\section{Tahap Pengembangan}

Tahap pengembangan ini terdiri dari penilaian validasi ahli, penilaian kepraktisan siswa terhadap modul statistika pada uji coba terbatas dan uji coba lapangan, dan penilaian keefektifan ditinjau dari tes hasil belajar menggunakan soal literasi statistis. Modul dirancang dan menghasilkan draft 1. Tahap selanjutnya adalah melakukan proses validasi ahli oleh dua orang validator. Adapun kualifikasi validator tersebut adalah doktor bidang pendidikan matematika. Proses validasi dilakukan dengan menggunakan lembar validasi dan modul statistika. Validasi oleh ahli dilakukan untuk melihat isi draf 1. Lembar validasi terdiri dari 4 aspek yang dinilai yaitu aspek isi modul, bahasa dan tampilan, ilustrasi, letak, tabel \& diagram, dan manfaat. Di bagian bawah lembar validasi disediakan temapat menuliskan saran dan komentar secara terbuka untuk selanjutnya direvisi. Selain itu, validator juga dapat menuliskan koreksi langsung pada draft modul yang diberikan. Modul yang sudah selesai diperiksa oleh validator dan dianalisis datanya, kemudian dismpulkan tentang kevalidan modul tersebut. Hasil dari proses validasi oleh ahli dapat dilihat pada Tabel 3.

Tabel 3. Hasil validasi ahli

\begin{tabular}{ccccc}
\hline Aspek yang dinilai & Validator 1 & Validator 2 & Validator 3 & Rata-rata \\
\hline Materi & 3,68 & 3,74 & 3,60 & 3,67 \\
Soal dan Latihan & 3,72 & 3,81 & 3,59 & 3,71 \\
Bahasa dan tampilan & 3,64 & 3,75 & 3,60 & 3,67 \\
Ilustrasi tabel & 3,69 & 3,72 & 3,55 & 3,65 \\
Manfaat & 3,67 & 3,74 & 3,65 & 3,69 \\
\hline \multicolumn{7}{r}{ Rata-rata semua aspek }
\end{tabular}


Berdasarkan Tabel 3, aspek soal dan latihan merupakan aspek yang memperoleh skor paling tinggi dari validator, sedangkan aspek ilustrasi tabel mendapatkan skor terendah dari kelima aspek. Rata-rata validasi modul 3, 68, artinya modul valid. Setelah melewati proses validasi dan mendapatkan hasil valid dengan sedikit revisi, dilanjutkan ke proses uji kepraktisan dan uji efektifitas (Bela et al., 2021). Selain memberikan penilaian, validator juga memberikan beberapa saran perbaikan yang menjadi bahan pertimbangan untuk memperbaiki draft modul selanjutnya. Hasil komentar dan saran dari validator tersebut dijadikan bahan untuk perbaikan modul draft 1 . Draft 1 yang telah diperbaiki ini, selanjutnya menjadi draft 2 .

\section{Diseminasi}

a. Uji Coba Terbatas

Modul draft 2 ini kemudian dilakukan uji coba terbatas oleh 15 orang siswa diminta untuk membaca dan memberikan komentar tentang modul yang dibaca sesuai dengan materi yang diminta, kemudian mengisi panduan uji keterbacaan oleh siswa. Data hasil uji coba terbatas siswa ini berdasarkan hasil isian lembar panduan uji keterbacaan siswa untuk setiap materi dapat dilihat pada Tabel 4

Tabel 4. Hasil Uji Coba Terbatas

\begin{tabular}{lc}
\hline \multicolumn{1}{c}{ Materi Per Bab } & Rata-rata \\
\hline $\begin{array}{l}\text { Ukuran Pemusatan data yang meliputi mean, median, dan modus } \\
\text { Ukuran Penyebaran data yang meliputi jangkauan, kuartil, jangkauan } \\
\text { antar kuartil, dan simpangan kuartil }\end{array}$ & 3,72 \\
\hline Rata-rata seluruh bab & 3,70 \\
\hline
\end{tabular}

Materi ukuran pemusatan data yang meliputi mean, median, dan modus diperoleh rata-rata sebesar 3,72 dan Ukuran Penyebaran data yang meliputi jangkauan, kuartil, jangkauan antar kuartil, dan simpangan kuartil diperoleh rata-rata sebesar 3,70, sehingga rata-rata seluruh bab 3,71.

Berdasarkan tabel 4 dapat dilihat bahwa hasil uji coba terbatas dari modul statistika yang dikembangkan diperoleh rata-rata skor 3,71 dari rentang penilaian 1 sampai dengan 4 dan menunjukkan hasil yang tinggi. Selain memberikan penilaian, siswa juga memberikan komentar dan saran. Komentar dan saran tersebut digunakan sebagai masukan dalam revisi modul. Hal ini menunjukkan bahwa modul statistika yang dikembangkan dilihat dari aspek penilaian materi sangat mudah dipahami oleh siswa dan guru.
Setelah melalui proses uji keterbacaan, draft modul 2 di revisi sesuai dengan saran dan masukan dari mahasiswa. Draft hasil revisi ini disebut draft modul 3. Draft ini akan digunakan untuk proses uji coba lapangan. Sesuai dengan penelitian (Nurmeidina, R., Lazwardi, A. \& Ariyanti, 2020; Qomario et al., 2014) setelah melalui proses uji keterbacaan draft modul direvisi, kemudian dilanjutkan untuk proses uji coba lapangan. Siswa diberikan modul, proses uji coba dan pembelajaran dilaksanakan secara daring dan dilaksanakan mandiri oleh siswa untuk berlatih soal pada modul.

\section{b. Uji Coba Lapangan}

Uji coba lapangan ini menghasilkan sejumlah data yang dianalisis untuk mengetahui kepraktisan dan keefektifan perangkat pembelajaran 
DOI: https://doi.org/10.24127/ajpm.v10i3.3779

yang dikembangkan. Kepraktisan dapat diketahui dari lembar penilaian kepraktisan oleh siswa. Sedangkan keefektifan dapat dilihat dari tes hasil belajar dengan soal literasi statistis.

c. Penilaian Kepraktisan oleh siswa Data dari lembar penilaian siswa digunakan untuk mengetahui kepraktisan dari modul yang dikembangkan. Lembar penilaian siswa ini diberikan setelah selesai melaksanakan pembelajaran menggunakan modul. Data hasil lembar kepraktisan siswa dapat dilihat pada Tabel 6 dan Tabel 7.

Tabel 6. Kepraktisan modul untuk materi per bab

\begin{tabular}{lc}
\hline \multicolumn{1}{c}{ Materi Per Bab } & Rata-rata \\
\hline Ukuran Pemusatan data yang meliputi mean, median, dan modus & 3,87 \\
$\begin{array}{l}\text { Ukuran Penyebaran data yang meliputi jangkauan, kuartil, jangkauan } \\
\text { antar kuartil, dan simpangan kuartil }\end{array}$ & 3,83 \\
\hline Rata-rata seluruh bab & 3,85 \\
\hline
\end{tabular}

Tabel 7. Kepraktisan modul dari aspek penilaian

\begin{tabular}{clc}
\hline No & Aspek Penilaian & Rata-rata \\
\hline 1 & Jenis tulisan, ukuran huruf dan bahasa & 3,83 \\
2 & Isi modul (gambar, tabel, uraian materi dan rangkuman) & 3,70 \\
3 & $\begin{array}{l}\text { Contoh soal dan latihan untuk kemandirian kemampuan literasi } \\
\text { statistis }\end{array}$ & 3,85 \\
4 & $\begin{array}{l}\text { Modul secara umum untuk kemandirian dan kemamapuan literasi } \\
\text { statistis }\end{array}$ & 3,86 \\
\hline & Rata-rata seluruh bab & 3,81 \\
\hline
\end{tabular}

Berdasarkan hasil pada Tabel 6 dan Tabel 7 didapatkan skor rata-rata penilaian siswa terhadap modul untuk setiap materi adalah 3,85 dan ditinjau dari aspek penilaian adalah 3,81 . Nilai tersebut termasuk dalam kategori kepraktisan tinggi.

Hal ini menunjukkan modul yang dikembangkan mendapat respon positif dari siswa, karena dengan adanya modul ini karena memudahkan mereka untuk belajar statistika. Selain itu, siswa memberikan masukan dan saran mengenai kekeliruan dalam penulisan, ukuran huruf dan angka, dan rincian penjelasan jawaban soal.

d. Aspek keefektifan ditinjau dari tes hasil belajar dengan soal literasi statistis.
Hasil tes menunjukkan terjadi peningkatan antara hasil pretest dan posttest. Rata-rata hasil pretest 55,48 , sedangkan rata-rata hasil posttest 84,27 terjadi peningkatan hasil tes sekitar $28,79 \%$. Sehingga, disimpulkan bahwa hasil pengembangan telah memenuhi aspek keefektifan. Selain itu, diperoleh hasil $80,45 \%$ siswa mendapat nilai di atas 65. Latihan soal pemahaman konsep dan literasi statistis pada modul membuat siwa memahami materi dengan baik dan dapat mengembangkan kemampuan literasi statistis.

Hal ini menunjukkan pembelajaran matematika menggunakan modul efektif sejalan dengan penelitian yang dilakukan oleh (Rachmawati \& Effendi, 2020; Ratih Kusumawati, 2018; Restu Lusiana, 2019) dan dapat meningkatkan 
penguasaan materi statistika dan kemampuan literasi statistis siswa (Nu'man, 2019; Furqoni \& Destania, 2020; Masfingatin \& Suprapto, 2020).

Implikasi dari penelitian ini, secara teoritis adalah modul yang dihasilkan dapat memudahkan siswa untuk memahami materi, meningkatkan minat untuk belajar statistika dan dapat memudahkan siswa untuk belajar dan berlatih sendiri. Adapun implikasi secara praktis atau penerapanya yaitu dengan soal-soal latihan kemampuan literasi statistis dan tes hasil belajar dengan kunci jawaban dapat melatih siswa mengevaluasi hasil pekerjaannya dan mengembangkan kemampuan literasi statistis merupakan implikasi dari penelitian ini secara praktis.. Selain itu juga penelitian ini dapat dijadikan acuan dalam pengembangan modul dengan materi lainnya.

\section{KESIMPULAN DAN SARAN}

Dari hasil dan pembahasan di atas, kesimpulan yang diperoleh dari penelitian ini yaitu menghasilkan modul statistika yang valid, praktis, efektif dan dapat memberikan fasilitas kepada siswa dalam mengembangkan kemampuan literasi statistis. Aspek kevalidan berdasarkan penilaian ahli menunjukkan bahwa modul pada kategori valid. Aspek kepraktisan berdasarkan penilaian siswa adalah tinggi. Aspek efektifitas berdasarkan tes hasil belajar dengan soal literasi statistis mengalami peningkatan berdasarkan hasil pretest dan posttest. Hasil pengembangan merupakan produk modul pembelajaran matematika dengan materi statistika yang valid, praktis dan efektif dan layak digunakan untuk MTs/ SMP kelas VIII. Saran untuk penelitian berikutnya adalah dapat melanjutkan penelitian eksperimen untuk mengukur pengaruh penggunaan modul statistika ini, baik untuk peningkatan kemampuan literasi statistis maupun kemampuan statistis lainnya seperti berpikir statistis, komunikasi statistis, penalaran statistis, dan disposisi statistis. Saran menyajikan hal-hal yang terkait penelitian ini atau yang akan dilakukan terkait dengan gagasan selanjutnya dari penelitian tersebut.

\section{DAFTAR PUSTAKA}

As'ari, A. R., Tohir, M., Valentino, E., Imron, Z., \& Taufiq, I. (2017). Buku Guru Matematika (Revisi). Pusat Kurikulum Dan Perbukuan, Balitbang, Kemendikbud Jakarta.

Azwar, S. (2012). Penyusunan Skala Psikologi. Yogyakarta. Pustaka Pelajar.

Bela, M. E., Wewe, M., \& Lengi, S. (2021). Pengembangan Modul Matematika Materi Aritmatika Sosial Berbasis Pendekatan Saintifik Untuk Siswa Kelas VII SMP. Jurnal Cendekia: Jurnal Pendidikan Matematika. https://doi.org/10.31004/cendekia. v5i1.461

Furqoni, A. N., \& Destania, Y. (2020). Pengembangan Soal Statistika Untuk Meningkatkan Kemampuan Koneksi Matematis Siswa. Alifmatika: Jurnal Pendidikan Dan Pembelajaran Matematika, 2(2), 212-228.

https://doi.org/10.35316/alifmatika .2020.v2i2.212-228

Gravemeijer, K., Stephan, M., Julie, C., Lin, F., \& Ohtani, M. (2017). What Mathematics Education May Prepare Students for the Society of the Future? 9814-6. International Journal of Science and Mathematics Education, 15, 105123. https://doi.org/10.1007/S10763017-. 
Hafiyusholeh, M., Budayasa, K., \& Siswono, T. Y. E. (2017). Literasi statistik: Siswa SMA dalam membaca , menafsirkan , dan menyimpulkan Data. Prosiding SI MaNIs (Seminar Nasional Integrasi Matematika Dan Nilai Isami), $\quad$ 1(1), 79-85. http://conferences.uinmalang.ac.id/index.php/SIMANIS/ article/view/41

Hariyanti, F. (2020). Statistical Literacy Siswa SMP dalam Pembelajaran Matematika. Ekspose: Jurnal Penelitian Hukum Dan Pendidikan.

https://doi.org/10.30863/ekspose.v $18 \mathrm{i} 2.564$

Irawati, S. (2017). Problematika Pembelajaran Statistik di Perguruan Tinggi Keagamaan Islam (PTKI). KABILAH : Journal of Social Community, 2(1), 202217.

https://doi.org/10.35127/kbl.v2i1.3 113

Jamil A, Cahyono H, A. M. (2021). Pengembangan Handout Matematika Bercirikan Kearifan Lokal Untuk Meningkatkan Kemampuan Literasi Matematis. AKSIOMA: Jurnal Program Studi Pendidikan Matematika, 10(1), 4862

DOI: https://doi.org/10.24127/ajpm.V10i 1.3260 ISSN 2089-8703 (Print) ISSN 2442-5419 (Online), 10(1), 48-62.

Kemdikbud. (2017). Buku Guru Matematika Kurikulum 2013 Revisi 2017.

Lestari, L., Sukasno, \& Hadayani, S. (2018). Analisis Kesalahan Siswa dalam Menyelesaikan Soal Statistika Kelas XI IPS 2 MA Negeri 2 Lubuklinggau Tahun Pelajaran 2016/2017. Program
Studi Pendidikan Matematika STKIP PGRI Lubuklinggau.

Maryati, I., \& Priatna, N. (2018).

Analisis Kemampuan Literasi

Statistis Siswa Madrasah

Tsanawiyah dalam Materi

Statistika. Journal of Medives:

Journal of Mathematics Education IKIP Veteran Semarang, 2(2), 205. https://doi.org/10.31331/medives.v $2 \mathrm{i} 2.640$

Masfingatin, T., \& Suprapto, E. (2020). Student's Statistical Literacy skills Based on the Reflective and Impulsive Cognitive Styles. AlJabar: Jurnal Pendidikan Matematika, 11(2), 273-286. https://doi.org/10.24042/ajpm.v11i 2.6902

Murod, R. R., Priatna, N., \& Martadiputra, B. A. P. (2019). The Scaffolding Approach to Enhance Senior High School Student's Statistical Literacy Ability. Journal of Physics: Conference Series, 1227(1).

https://doi.org/10.1088/17426596/1227/1/012028

Muzaki, L., Slamin., \& Dafik. (2014). Pengembangan Perangkat Pembelajaran Berbasis Metode Guided Discovery Learning Berbantuan E-Learning dengan Apliksai Atutor pada Pokok Bahasan Lingkaran Kelas VIII SMP. Pancaran, 3(2), 25-34.

Nahdi, D. S., Araniri, N., Jatisunda, M. G., Kurino, Y. D., \& ... (2021). Statistical Literacy of Pre-Service Islamic Religious Education Teachers. Jurnal Cendekia: Jurnal ..., 05(02), 900-908. https://jcup.org/index.php/cendekia/article/ view/494

Nu'man, M. (2019). Pengembangan Bahan Ajar Statistika Penelitian Pendidikan Matematika. 3(2), 
DOI: https://doi.org/10.24127/ajpm.v10i3.3779

\section{4-128.}

Nurmeidina, R., Lazwardi, A., \&, \& Ariyanti, I. (2020). Pengembangan Modul Teori Peluang untuk Meningkatkan Hasil Belajar dan Disposisi Matematis. AKSIOMA: Jurnal Program Studi Pendidikan Matematika, 9(2), 440-450. Jurnal Pendidikan Matematika.

Priatna Martadiputra, B. A. (2012). Peningkatan Kemampuan Berpikir Statistis Mahasiswa S1 Melalui Pembelajaran MEAs yang Dimodifikasi. Infinity Journal, 1(1), 79. https://doi.org/10.22460/infinity.v1 i1.8

Pujiastuti, H. \& Haryadi, R. (2021). Pengembangan Modul Matematika Berbasis Kontekstual Pada Materi Aljabar. AKSIOMA: Jurnal Program Studi Pendidikan Matematika, 10(1), 2021, 63-72 https://doi.org/10.24127/Ajpm.V10 il.3392 ISSN 2089-8703 (Print) ISSN 2442-5419 (Online), 10(1), 63-72.

Qomario, Koestoro, B., \& Herpratiwi. (2014). Pengembangan Bahan Ajar Modul Matematika Kelas VIII SMP di Bandar Lampung. Jurnal Teknologi Informasi Komunikasi Pendidikan.

Rachmawati, A. D., \& Effendi, M. M. (2020). Developing Web-Assisted Interactive Media to Improve Mathematical Creative- Thinking Ability. 11(2), 211-226.

Ratih Kusumawati, A. N. (2018). Developing Mathematics Learning Strategy Module Based on Journal Review. Al-Jabar: Jurnal Pendidikan Matematika Vol. 9, No. 2, 2018, Hal 111 - 120, 111-120.

Rembulan, A., Wahyu, R., \& Putra, Y. (2018). Pengembangan Bahan Ajar Gamifikasi pada Materi Statistika
Kelas VIII. Jurnal Matematika Dan Pendidikan Matematika Vol. 3 No. 2, 3(2), 84-98.

Restu Lusiana, T. A. (2019). Developing an Algebra Textbook Based on Problem Solving to Improve Student' Learning Achievement. Al-Jabar: Jurnal Pendidikan Matematika Vol. 10, No. 2, 2019, Hal 293 - 306, 10(2), 293-306.

Ruhyana. (2016). Analisis kesulitan siswa dalam belajar statistik khususnya pada histogram. Jurnal Computech \& Bisnis, 10(2), 106118.

Sabbag, A., Garfield, J., \& Zieffler, A. (2018). Assessing statistical literacy and statistical reasoning: The reali instrument. Statistics Education Research Journal, 17(2), 141-160.

Sharma, S. (2017). Definitions and models of statistical literacy: a literature review. Open Review of Educational Research, 4(1), 118133.

https://doi.org/10.1080/23265507.2 017.1354313

Thiagarajan, S., Semmel, D. S., \&, \& Semmel, M. I. (1976). Instructional development for training teachers of exceptional children: A sourcebook. In Indiana University. Https://Doi.Org/10.1016/00224405(76)90066-2.

Tiro, M. A. (2018). Strategi Aksi Gerakan Nasional Literasi Statistika di Indonesia. Seminar Nasional Variansi (Venue Artikulasi-Riset, Inovasi, Resonansi-Teori, Dan Aplikasi Statistika). 